\title{
PŘÍBĚHY ZMĚNY VE SKUPINOVÉ PSYCHOTERAPII: NARATIVNÍ CHARAKTERISTIKY ÚSPĚŠNÉ ZMĚNY
}

\author{
Eva Dubovská \& Vladimír Chrz
}

\begin{abstract}
Abstrakt
Cílem studie je popsat narativní charakteristiky vyprávění o změně u klientů skupinové psychoterapie, kteří dosáhli klinicky významné změny. Studie byla součástí trríletého projektu, zaměřeného na výzkum efektivity a faktorů psychoterapie $\mathrm{v}$ denních stacionářích pro léčbu úzkostných poruch a deprese. Léčba trvala 3 měsíce, klienti docházeli do stacionáře vždy v pracovní dny. Sběr dat probíhal v letech 2014 až 2016, $\mathrm{z}$ celkového počtu $\mathrm{n}=220$ klientů (celkově 21 skupin $\mathrm{v}$ délce trvání 12 týdnů) v kvantitativní části projektu se opakovaných rozhovorů v kvalitativní části (uprostřed léčby, na jejím konci a 9 až 10 měsíců po ukončení léčby) účastnilo 32 klientů.

Prezentovaná studie pracuje s užším výběrem osmi klientů, kteří absolvovali nejméně dva rozhovory a dle objektivních ukazatelů měření změny v psychoterapii dosáhli klinicky významné změny. Data byla analyzována pomocí kategorické narativní analýzy za užití narativních kategorií: témata změny; aktérství; narativní pozice; hodnoty a přesvědčení. Ukazuje se, že u některých klientů dochází v průběhu procesu změny ke „zrodu“ aktérství, k jakési re-autorizaci vlastního jednání. Objevují se zde dvě varianty aktérství, systematicky režisérský typ a uvolněnější, otevřenější typ. V kategorii narativní pozice se klienti vymezují k ostatním členům skupiny jako i vůči celé skupině a také jako skupina vůči „zbytku světa“. V kategorii hodnoty a přesvědčení se ukazuje hodnotový a normativní aspekt dosažení změny v psychoterapii.
\end{abstract}

Klíčová slova: změna v psychoterapii, narativní analýza, aktérství

\section{STORIES OF CHANGE IN GROUP PSYCHOTHERAPY: NARRATIVE CHARACTERISTICS OF SUCCESSFUL CHANGE}

\begin{abstract}
The main goal of the study is to describe narrative characteristics of stories of change in psychotherapy group, narrated by clients, who reached clinically significant change. The current study was a part of a three-year project, focused on the research of efficiency and curative factors of therapy in daily treatment centres specialized at treatment of depression and anxiety disorders. From the total participants $n=220$ (21 groups) in the quantitative part of the project, 32 clients took part in repeated qualitative interviews (in the middle, at the end of treatment, and $8-9$ months after treatment).

The present study involves eight participants who participated in at least two interviews and reached a clinically significant change. Data were analysed by means of categorical narrative analysis, using the following narrative categories: thematic lines; agency; positioning; values, and beliefs. Results indicate, that some clients develop the agentic capacity only during the process of change, it is a certain "re-authorisation " of one's action. There appear to be two types of agency, a systematic, directive type and more relaxed, open type. In the category of positioning, clients tend to the narrative delimitation toward other members of group and also toward the group as a whole. In the category of values and beliefs, clients describe normative and moral aspects of reaching the change in psychotherapy.
\end{abstract}

Keywords: change in psychotherapy, narrative analysis, agency

Došlo: 19. 1. 2020

Schváleno: 30 . 6. 2020 


\section{Úvod}

Otázce, jak funguje psychoterapie a jak vlastně probíhá proces změny v psychoterapii, byl v posledních desetiletích věnován velký objem odborné literatury a doposud nedošlo ke shodě (Kazdin, 2009). Někteří autoři zdůrazňují, že ve výzkumu procesu změny v psychoterapii je často opomíjena perspektiva klienta: klienti nejsou pasivními př́jemci intervencí, stupeň jejich zapojení silně ovlivňuje výsledek terapie (Bohart, 2010; Lewitt et al., 2016).

Aktivní podíl klienta na průběhu a výsledku psychoterapie byl popsán detailně již v kvalitativních studiích Davida Rennieho, který zdůrazňoval především roli aktérství (agency) a reflexivity (Rennie, 1990; 2001). Mackrill (2008) při studiu deníků klientů popsal, jak klienti svým vlastním způsobem aktivně integrují zkušenosti z terapie do svého běžného života. Moertl \& Von Wietersheim (2008) zjistili, že klienti pracují na své změně i mimo terapii, naprríklad tím, že řeší svou terapii $\mathrm{v}$ rozhovorech $\mathrm{s}$ rodinou a práteli, čtou svépomocnou literaturu anebo přemýšlejí o dění v terapii. Podobně Kühnleinová (Kühnlein, 1999) poukázala na důležitost integrace zážitků z psychoterapie do celkového životního př́běhu a význam této integrace pro subjektivně pocit'ovanou změnu.

Jednou z možností, jak empiricky sledovat faktor klienta „při práci“ v procesu dosahování změny v psychoterapii, je narativně zaměřený výzkum, který umožňuje sledovat, jak klienti narativně ztvárňují své prožívání, jaké jsou vlastnosti tzv. narativní konstrukce př́běhů, jinými slovy: jak klienti své změně rozumí a jak toto svoje rozumění artikulují. Příběh nám totiž ř́íá mnohé o vyprávějícím, nese většinou více než jeden explicitní význam: v príbězích se konstruuje subjektivní chápání kauzality, důvody pro různé jednání postav vystupujících v př́iběhu a hodnocení tohoto jednání, které vyjadřuje určité morální přesvědčení vyprávějícího (Bruner, 1996; Čermák, 2002).

Významným přispěním $\mathrm{k}$ narativním výzkumům změny $\mathrm{v}$ psychoterapii je např́íklad dílo Jonathana M. Adlera $(2008 ; 2012)$, který se na změnu dívá z perspektivy teorií narativní identity, tedy internalizovaného a neustále se vyvíjejícího př́běhu self (McAdams, 1996). Hlavním narativním konstruktem, kterým se Adler zabýval, bylo aktérství a koncept narativní koherence. Aktérství Adler definuje jako „narativní instanci jedné z hlavních psychologických sil, tvarujících lidský život, související s autonomií individua, dosahováním jeho cílů, dovednostmi, schopností ovlivňovat směřování svého života“" (Adler, 2012, s. 368). Ve studii narativů, psaných po ukončení psychoterapie (Adler et. al., 2008), se ukázalo, že klienti, jejichž psané narativy o léčbě vykazovaly vysokou míru aktérství, mnohem pravděpodobněji dosahovali lepší úrovně životní pohody a osobní zralosti (Adler et al., 2008). V náročném designu longitudinální studie, v níž klienti po dobu 12 měsíců psali rozsáhlé narativy po každém terapeutickém sezení, zase zvýšení úrovně aktérství predikovalo terapeutickou změnu (Adler, 2012).

Kromě aktérství mezi nejčastější konstrukty, které jsou ve výzkumu procesu změny sledovány narativně, a to prostřednictvím tzv. narativních skórovacích systémů, patří např́íklad reflexivita, integrace a vyjádření emocí (Angus, 2012) a úroveň explorace a inovace v naraci (inovativní momenty) (Gonçalves et al., 2009). Další, zatím méně početné, studie pracují s konceptem sebe-definujících vzpomínek (self defining memories) (Singer et al., 2013), anebo s analýzou žánru (Thornhill, Clare, \& May, 2004). Narativní analýza se často uplatňuje i při tvorbě př́ípadových studií (Lieblich et al., 2004; Angus \& Kagan, 2013).

Hlavním cílem této studie je popsat, jaké jsou narativní charakteristiky př́iběhů úspěšné změny, aneb co je typické pro př́iběhy změny klientů, kteří se ve skupinové psychoterapii uzdravili anebo výrazně zlepšili, klientů, kteří si takzvaně dokázali „,vzít z terapie maximum“. 


\section{Metody}

Studie byla součástí trríletého projektu, zaměřeného na výzkum efektivity a faktorů psychoterapie $\mathrm{v}$ denních stacionáŕích pro léčbu úzkostných poruch a deprese. Léčba trvala 3 měsíce, klienti docházeli do stacionáře vždy v pracovní dny. Sběr dat probíhal v letech 2014 až 2016, $\mathrm{z}$ celkového počtu $\mathrm{n}=220$ klientů (celkově 21 skupin v délce trvání 12 týdnů) v kvantitativní části projektu se rozhovorů v kvalitativní části účastnilo 32 klientů. Studie byla schválena etickou komisí Pražské vysoké školy psychosociálních studií. Všichni klienti podepsali informovaný souhlas. Před začátkem každého rozhovoru byli klienti informováni o svém právu kdykoliv svou účast ve výzkumu odvolat a o naprostém zachování jejich anonymity. Data byla anonymizována tak, že byla změněna jména klientů i některé další charakteristiky.

\section{Léčebný program}

Pobyt v denním stacionáři pro pacienty s úzkostnými, depresivními a psychosomatickými problémy má standardní délku trvání 12 týdnů. Klienti docházejí do prostor kliniky, kde od rána probíhá skupinová psychoterapie (integrativního typu, se zaměřením na interpersonální dynamiku). Odpoledne mají klienti doplňkový program, jako jsou nácviky relaxace, arteterapie, biblioterapie, muzikoterapie. Mezi další specifika terapeutického programu patří životopisné skupiny, setkání s rodinnými př́slušníky, společná vycházka a týdenní rekapitulace. Složení terapeutů na klinice je co do preferovaných terapeutických směrů i pohlaví a délky zkušenosti smíšené.

\section{Výzkumný vzorek}

Z celkového počtu 32 klientů, kteří absolvovali rozhovory o své změně v psychoterapii, jsme pro tuto studii zvolili ještě užší výběr, a to 8 klientů, kteří na základě měření účinku psychoterapie vykázali klinicky signifikantní změnu (Jacobson \& Truax, 1991) a byly s nimi realizovány minimálně dva rozhovory.

Účinnost psychoterapie se měřila na začátku, v 6. a ve 12. týdnu léčby pomocí dotazníků CORE-OM (Juhová et al., 2018) a SCL 90-R. V tabulce č. 1 jsou uvedeny demografické ukazatele a hodnoty celkového průměrného skóre v dotazníku SCL 90-R a CORE-OM na začátku (GSI/CO1) ${ }^{1}$ a na konci terapie $(\mathrm{GSI} / \mathrm{CO} 2)$ u všech vybraných pacientůํㄹ

Tabulka č. 1 Demografické údaje a skóre dotazníků SCL 90 R a CORE-OM

\begin{tabular}{|c|c|c|c|c|}
\hline Přezdívka & Věk & Vzdělání & GSI /CO 1 & GSI / CO 2 \\
\hline Anna & 38 & VŠ & $1,97 / 2,44$ & $0,72 / 0,85$ \\
\hline Eva & 23 & $\mathrm{SS}$ & $1,94 / 2,27$ & $0,47 / 0,47$ \\
\hline Hanka & 43 & ŠS & $1,44 / 2,00$ & $0,04 / 0,32$ \\
\hline Zuzana & 46 & V $\breve{S}$ & $2,17 / 2,32$ & $0,64 / 0,76$ \\
\hline Lenka & 26 & $\mathrm{SS}$ & $1,58 / 2,00$ & $0,25 / 0,15$ \\
\hline Marie & 44 & V̌S & $1,07 / 1,94$ & $0,67 / 0,94$ \\
\hline Petr & 49 & $\mathrm{SS}$ & $1,47 / 1,88$ & $0,33 / 1,00$ \\
\hline Milan & 22 & ŠS & $0,72 / 1,41$ & $0,20 / 0,18$ \\
\hline
\end{tabular}

\footnotetext{
${ }^{1}$ GSI: Global Severity Index, průměr všech odpovědí dotazníku SCL90-R

${ }^{2}$ Výpočet efektivity psychoterapie celého vzorku $\mathrm{N}=220$ prokázal signifikantní změnu při $p<0,001$ a míre účinku Cohenovo d 2,03 pro GSI a 2,24 pro CORE OM (Dubovská et al., 2019).
} 


\section{Průběh rozhovorů}

Rozhovory byly realizovány v 6 . a ve 12. týdnu pobytu ve stacionáři a následně 9 až 10 měsíců po ukončení léčby. Scénář rozhovoru byl polostrukturovaný, zaměřený na změnu, klientovo pochopení změny a terapeutické faktory (co pomáhá). Rozhovor začínal delší narativní částí, s otázkou: „Prosím, vyprávějte mi tak nějak od začátku - jaké to tady pro vás je, jak se tady máte?“. Hlavní okruhy rozhovoru byly: co se změnilo; v co klienti doufali, že se změní a nezměnilo se; změnilo se něco k horšímu; jak těmto změnám rozumějí; nejsilnější a nejtěžší momenty v terapii; pomáhající/bránící faktory terapie. V rozhovorech byl kladen důraz na to, aby měli klienti dostatek prostoru vyjádřit se ke všem aspektům svého prožívání jak v stacionáŕi, tak i mimo něj. Rozhovory byly následně přepsány doslovně (verbatim).

\section{Opatření pro zvýšení důvěryhodnosti výzkumu}

Při př́ípravě a realizaci studie jsme se ř́́dili doporučeními pro zvýšení důvěryhodnosti kvalitativního výzkumu (Lincoln \& Guba, 1985) a také doporučeními pro narativní analýzu (Riessman, 2008; Čermák, 2002). V průběhu sběru dat byl veden výzkumný deník a v průběhu analýzy dat byl pořizován tzv. auditní záznam, většinou ve formě audionahrávek diskusí se supervizorem (druhým autorem) analytické části práce. Autoři se v diskusích věnovali zejména hledání významů a souvislostí v datech a možných zkreslení. Př́íklon obou autorů k humanistické psychologii mohl zvýraznit i některé významy, které byly nalezeny v procesu analýzy, a to zejména koncepty aktérství, hledání smyslu, autenticity.

\section{Analýza dat}

Kategorická narativní analýza (Lieblich, Tuval-Mashiach, \& Zilber, 1998; Chrz, 2004) přepisů rozhovorů byla provedena ve třech na sebe navazujících krocích: prvním krokem bylo otevřené kódování a identifikace vynořujících se způsobů ztvárnění zkušenosti. Druhý krok spočíval v opakované analýze typu ,zig-zag“ anebo zdola-nahoru / shora-dolů, pro niž byl charakteristický pohyb od identifikovaných vzorců ztvárnění zkušenosti k narativním konceptům a teoriím a poté zpět k datům, s cílem sestavení analytického schématu a kategorií. Třetí fáze analýzy spočívala $\mathrm{v}$ opětovné analýze všech dat, nyní už z pohledu vytyčených kategorií, kterými byly: témata změny, aktérství, narativní pozice, hodnoty a přesvědčení.

\section{Zjištění}

\section{Témata změny}

Témata změny chápeme jako výchozí kategorii analýzy, a to nejen z důvodu její jednodušší uchopitelnosti, ale také proto, že vhodně otevírá a představuje povahu zkoumaného materiálu. V rozhovorech o změně v psychoterapii dávají klienti vždy určitý výraz tomu, „o čem jejich změna je“, přitom toto „něco“ chápeme jako téma. Za účelem umožnit pochopení každého klienta $\mathrm{v}$ jeho jedinečné situaci budou témata $\mathrm{v}$ této kategorii představena pro každého participanta zvlášt'. 
Tabulka č. 2 Témata změny

\section{Eva}

- znovunalezení sebe sama a svých hodnot, „postavit se za sebe a stát si za tím “

- nebát se ř́́kat svi̊j názor

- „coming out“ před přáteli - přiznat si nemoc je osvobozující

- přehodnocení vztahů s rodiči

- nemusí se vším souhlasit - nesouhlas nebude potrestán

\section{Zuzana}

- byla ve svém zaměstnání „příliš hodná “ a neznala své hranice

- odpuštění a pochopení své matky

- sebepřijetí: ona je ta, která „jde věčně proti proudu“

- dělat něco, co má větší smysl

\section{Marie}

- „,nechala se zavést takhle daleko“ - nerespektovala své hranice v práci

- uvědomuje si, že se vždy př́liš podřizovala ostatním

- lepší pochopení svého manžela, díky jinému členu skupiny

- chce dělat „práci, která má smysl“

\section{Lenka}

- sebepřijetí: „Mám v sobě diru, kterou musím nějak zalepit, a můžu to udělat jenom já sama“

- vyrovnání se s bolestivým rozchodem po dlouhodobém vztahu

- znovu otevírá trauma ze zneužívání v dětství

- učí se mluvit o těžkých věcech, podpora skupiny „strašně pomáhá “

\section{Milan}

- postavit se sám za sebe, dělat věci podle sebe

- nemít kvůli všemu výčitky svědomí

- skupina mu pomáhá v období, kdy se osamostatňuje od rodičů a hledá si první práci

\section{Petr}

- přebrání odpovědnosti za svůj život, „Nikdo to za mne nerozhodne, musím sám “

- rozhodnutí odejít od rodiny a od manželky

- poznat a prosazovat svá práva

- vlastní iniciativa, ,popasování se s nabídkami změn “

\section{Anna}

- uvědomění si toho, jak je důležitá otevřenost ke všemu, co se děje v terapii

- dokázala se za sebe postavit $\mathrm{v}$ konfliktu s dalším členem skupiny

- podobně i v životě se učí „, ustát si to svoje, nepřizpưsobovat se“

- přehodnocení vztahů v rodině, otec je ,, sobec a pokrytec“"

\section{Hanka}

- byla k ostatním „přiliš hodná“

- díky zpětné vazbě členů skupiny zjistila, že není tak špatná, jak si myslela

- pochopení toho, co se jí dělo v dětství - byla často sama, opuštěná, zanedbaná

- ukončení nevyhovujícího vztahu v důsledku zvýšení sebeúcty, uvědomila si, že „, stojí sama za to “ 


\section{Aktérství (agency)}

Ve zkoumaných narativech je častým úkazem moment jakéhosi objevení, vynoření anebo nalezení aktérství, jako vlastní kompetence, jakési „re-autorizace“ jednání (Epston \& White, 1992). Tyto momenty jsou většinou popisovány jako významné události v terapii a dokonce k tomu někdy dochází až po ukončení terapie. Klienti hovoří o momentech, kdy si uvědomili, že změna je v jejich režii, že mají na svou změnu vliv a že si to mohou dovolit. Vyprávějí o tom, jak si uvědomili, že se mohou ,postavit sami za sebe“, že se konečně ,postavili na svoje nohy“, že zjistili, že „stojí za to“, aby udělali „něco pro sebe“.

Ve vyprávění klientů se aktérství projevuje zejména $\mathrm{v}$ aktivním postoji zaměřeném na dosažení změny, „práci na sobě“, postavení se sám/sama za sebe. Klienti vyprávějí o tom, jak bojují se symptomy, jak jsou odhodláni jít „naplno“ do terapie, i když to je někdy bolestivé, a také jak i v životě mimo terapie přijímají výzvy životních situací a podstupují jednání, které je odpovědí na tyto výzvy. Typické je používání první osoby jednotného čísla.

Jak již bylo zmíněno, u některých klientů se kapacita pro aktérství objevuje až v průběhu terapie a projeví se většinou jako náhlé uvědomění si své nové možnosti jednat. Hanka naprríklad popisuje, jak se asi dva měsíce po ukončení léčby začaly dít změny v jejím príistupu k sobě, jak si uvědomila, že „stojí sama za to“:

„No, nejdř́v se jakoby nedělo nic, potom konec února, spíš ten březen, duben ehm... se to začalo nějakým způsobem jako kdyby ehm... dít samo, jo, jako kdyby to prostě přišlo samo od sebe, pak jednou jsem si uvědomila... jsem si prostě jakoby v sobě rekla, že stojím sama za to, abych... abych si taky dopřála něco pro sebe... že prostě si ohlídám to, co je pro mě di̊ležitý a... na tom není nic špatného. “

Pokud se díváme na projevy aktérství obecně, rozlišili jsme v našem vzorku dvě hlavní tendence, anebo „typy“ aktérství, které se liší tím, nakolik je změna plně v režii aktéra.

Aktérství Evy je příkladem systematického, autorského aktérství, možná by se dalo říct trochu umanutého. Eva drží svůj př́stup ke změně pevně v rukou, má to pod kontrolou, neponechává nic náhodě. Eva vypráví o tom, jak si začala sama od sebe (bez doporučení terapeutů) psát deník s cílem prripravit se předem na své vystoupení na skupině: Eva má jasný cíl - chce získat z terapie maximum. Příležitost, že se účastní psychoterapie, vnímá jako jedinečnou šanci, kterou musí využít naplno. Chce to udělat co nejlíp, vytěžit $\mathrm{z}$ toho co nejvíc, jedná se o specifickou podobu režie - mít to pod kontrolou, nenechávat to náhodě:

„Já jsem si, já jsem si včera začla psát deník. Říkala jsem si, že, že mi to třeba pomůže, když si jako na skupině vezmu jako to slovo, takže si doma nejdřiv jako promyslím to, že tam jako, že to jako napišu, pak si to znova jako přčctu, tak mě... Třeba dneska jsem si vzala skupinu a to, že jsem si to včera ňák jakoby sepsala, tak mi jako to ňák jako pomohlo dát tomu, já nevím, hlavu a patu nebo ňákou kostru.“"

Dále Eva říká, že nechce, aby ji ostatní členové skupiny šetřili, chce, aby jí řekli všechno, co jim na ní vadí, na čem by měla pracovat, protože se chce zlepšit a zlepšovat. Opět je její přístup ke změně plně v její režii.

V kontrastu k aktérství Evy je tady aktérství Petra, které je jaksi otevřenější, receptivnější vůči nabídkám, jež přicházejí zvenčí, a to vždy o něco dřív, než je na ně připravený. Petr prostě umí nechat tyto nabídky a nové možnosti k sobě přicházet a reaguje na ně aktivním způsobem. Jeho režie není kontrolující ani umanutá, ale naopak otevřená a možná také trochu impulzivní. 
Petr vypráví o tom, jak dostal nečekanou velmi dobrou nabídku na práci, tak nabral odvahu a znovu po malých krocích začal znovu jezdit jako profesionální řidič, a to i navzdory tomu, že právě za volantem se u něho před léčbou objevovaly těžké úzkostné stavy:

„P: Od toho stacíku přicházej změny a nabídky změn, který já vnímám a který jsou vždycky o trochu rychlejší než jsem já. To znamená, že chvilku pred tím, než jsem připravenej, tak přijde ňáká možnost změny nebo něčeho novýho. Já to musím rychle zpracovat, rychle se dotáhnout, tak abych s tou nabidkou byl srovnanej a abych na to mohl rychle zareagovat, než mi to uteče. No a ve spoustě věcí se mi to daří. "

\section{Zaujímání narativní pozice (positioning)}

Mluvčí se aktivně sociálně umíst'ují, využívajíce dostupné meta-narativy (anebo dominantní diskurzy), nebo alternativně konstruují vlastní „proti-pozice“ (Bamberg, 2005), nebo také „interakční pozice“ (Madill, Sermpezis, \& Barkham, 2005). Některé znaky vyprávění mohou tedy signalizovat pozici mluvčího nebo také jeho hledisko, tedy určité rozvržení ve vztahu k ostatním, a to jak k těm, o nichž se mluví, tak i k těm, se kterými se mluví. Výběrem diskurzivních prostředků lidé typicky vymezuji hranice kolem sebe a druhých tak, že se zviditelní individuální rozdíly a př́śslušnost ke skupinám (Davies \& Harré, 1990; Bamberg, 2005).

Narativní pozice se ve vyprávění klienti̊ projevují několika významnými způsoby:

\section{I.a narativní pozice já vs. členové skupiny - identifikace a připisování zásluh}

Tento typ narativní pozice může mít několik cílů. Vypravěč se může například identifikovat s chováním/vlastnostmi členů skupiny, třeba mu nějaké chování dalšího člena skupiny může dodat odvahu, aby se podobně choval sám. Další klienti připisují dalším členům skupiny zásluhu při dosažení svého vhledu. Jednak druzí „nastavují zrcadlo“, na základě čehož si klient zdůvodňuje svou dosaženou změnu, anebo druhý člen skupiny může také zprostředkovat pochopení chování klientových blízkých, což následně napomáhá ke změně.

\section{I.b narativní pozice já vs. členové skupiny - vymezování se viǒci druhým}

Větší část klientů v rozhovorech konstruuje svou pozici vůči ostatním klientům s cílem vymezit se proti chování a vlastnostem jiných členů skupiny. Poukazují především na členy skupiny, kteří se podle nich dostatečně nesnaží, nejsou dost otevření, brzdí celou skupinu, zabírají př́lišs mnoho času s nulovým efektem, všechny návrhy od ostatních odmítají, chovají se nekonstruktivně. Tím i vlastně upevňují svou vlastní identitní pozici ,já jsem ten, kdo se snaží, kdo pracuje na změně“.

\section{II. narativní pozice já vs. skupina a skupina vs. ostatní svèt:}

Klienti konstruují také umíst'ování se ve vztahu k celé skupině, jde o identifikaci se skupinovými cíli, nalezení (anebo nenalezení) pocitu, že klienti do skupiny patří, že se cítí být její součástí. Pro zdůraznění sounáležitosti vůči skupině je pro některé klienty důležité umístit terapeutickou skupinu ve vztahu k jiným svým sociálním skupinám, jako např́klad srovnávání terapeutické skupiny s tím, jak to funguje/nefunguje v rodině, ve skupině přátel anebo v práci. 


\section{Hodnoty a přesvědčení}

Narativní konstrukce zhodnocuje určité cíle a zdůvodňuje či ospravedlňuje jednání aktérů, které směřuje k naplnění těchto cílů, a to právě prostřednictvím ztvárnění určitého systému hodnot a přesvědčení. Ústředním bodem narativní konstrukce je dle Brunnera (1996) narušení obvyklého, řádného či očekávaného, pro něž je užíván termín „potíž“ (trouble). Systémy hodnot tedy nejlépe chápeme právě v jejich souvislosti s potíží: jak hodnoty a přesvědčení odpovídají na výzvy potíží (Chrz, 2004). „Potíží“ je zde samotná nemoc tak, jak se projevuje v omezení životních možností klientů. Hodnoty a přesvědčení jsou ztvárněny jako odpovědi na otázky ,jak správně jednat, aby bylo dosaženo změny“, „oč má cenu usilovat ve změně“, „jak správně přistupovat k terapii““, ale i „co je důležité v životě, když se chci změnit“", a jak je dosažení změny zdůvodněno, zhodnoceno a přehodnoceno (ve vztahu k ,potíže versus optimum“).

Ve vyprávění klientů jsme identifikovali následující subkategorie ztvárnění hodnot a přesvědčení:

\section{Vysvětlování a autobiografické zdůvodňování}

Klienti nalézají v procesu psychoterapie nová vysvětlení svých problémů, konstruují si př́iběhy o původu a důvodech své nemoci, přepisují svůj životní př́běh, vytvářejí teorie své změny. Další klienti v rámci svých př́iběhů změny rekonstruují svoji minulost takovým způsobem, aby byla pro ně uchopitelná, aby dodala smysl prožité nemoci. Tyto prŕiběhy se zejména v katamnestických rozhovorech vyznačují vysokou koherencí a pozitivním vyústěním.

Zuzana např́klad vypráví o tom, jak díky nemoci pochopila svou (ted’ již mrtvou) matku, která jí byla celý život dost vzdálená a trpěla endogenní depresí. Připouští, že její onemocnění přišlo proto, aby jí bylo umožněno svou matku konečně pochopit:

„Já si prostě někdy řikám, jaký je ten život absurdní, že já jsem se najednou ocitla na podobným místě, i když ve zmenšené formě, abych si mohla zažit něco podobného jako ona (matka), a je to možná proto, abych ji pochopila. A právě když kolikrát odejdu z tý skupiny a jsem doma, tak prostějako na ni vzpomínám, chce se mi plakat a říkám si, jak ona musela být sakra silná. “

\section{Zhodnocování a přehodnocování}

Klienti ve svém vyprávění často zmiňují hodnoty, které jsou pro ně samé ústřední v jejich přístupu k léčbě, ke změně. Jako nejdůležitější vůbec se jeví otevřenost, a to nejen ke změně, ale i k novým významům.

Lenka vypráví o tom, jak si díky terapii uvědomuje omezenost svého subjektivního pohledu na svět a jak to bylo důležité pro její změnu:

„,Uvědomila jsem si, že se dá vždycky na nějakou věc podivat z více úhlư, že třeba já jsem měla tendenci zjednodušovat do nějaký negativní emoce, nebo něco a ono vlastně... třeba o sobě si myslím, že jsem špatná, ale vlastně vždycky to má víc vrstev. “

Další výrazná skupina hodnot, souvisejících s dosažením změny, se týká sounáležitosti, vzájemné podpory a tolerance, akceptace jinakosti a lidské jedinečnosti. Zuzana vyzdvihuje v souvislosti $s$ dosažením své změny opravdovost a hloubku dění na skupině, která vede k prohloubení autenticity:

„,Tady citite jakoby takovou tu hloubku, zároveň takový hluboký soucit, že tady ty věci, které se tady odehrávaji, jsou... opravdové. Že tady není někdo, aby někoho zaujmul, anebo to... ale že, že tady je to takové skutečné. Tady už neni prostor ze sebe dělat něco 
jiného, než co ve skutečnosti jste. Takže tady se opravdu odhalite na to hrubé jádro, které v sobě máte. “

\section{Hledání smyslu, akceptace a smírení}

$\mathrm{V}$ narativech se často objevují také víc existenciální témata. Hledání smyslu se projevuje především jako touha po práci, která by klienty bavila, touha po smysluplném využití času, který jim zbývá, a také po využití své jedinečnosti.

Anna vypráví o tom, jak se smíŕila sama se sebou:

„,změnilo se, prostě tak, já nevím, jakože určitě stojím opravdu pevně na nohou, že to, co mám, jsem spokojená v tom, co mám, ale není to žádná faleš. Že... že vím, co bych chtěla, že si postupně uvědomuju, co bych chtěla dělat, a realizuju to. “

Zuzana $\mathrm{v}$ průběhu terapie řešila problémy $\mathrm{v}$ zaměstnání, přišla na to, že ji práce nebaví a nenaplňuje. Uvědomuje si (nejenom) svoji jedinečnost:

„Uvědomuju si jedinečnost každého, že není dobře se strkat a zařazovat do toho hlavního proudu, že každá ta jedinečnost toho konkrétního člověka má nějaký svůj smysl, že to prostě není náhodou, jen tak, že jsme každý jiný, pravě jsme na základě toho svého př́běhu, který si neseme, tak bychom ho měli pochopit a posunout se někam dál a najít nějaké své poslání.“

\section{Diskuse}

Zkušenost 3měsíčního pobytu $\mathrm{v}$ denním stacionáři a každodenní skupinové psychoterapie samozrejmě musí zanechat výrazný „otisk“ v př́iběhu změny klienta. Jak bude tento otisk ztvárněn, závisí na mnoha faktorech, zejména na úspěšnosti terapie, tedy na tom, jestli toto období bude zpětně subjektivně vnímáno jako období změny a osobního růstu. V našich rozhovorech tomu tak je, protože jsme cíleně vybrali klienty, kteří si dokázali z terapie vzít „maximum“, dokázali se do procesu léčby zapojit takovým způsobem, že se vyléčili, anebo př́znaky nemoci výrazně ustoupily.

Když se podíváme na naše zjištění v kontextu jiných studií, nalezneme mnoho styčných bodů. Ústřední roli v úspěšném příběhu změny hraje aktérství, což odpovídá teoriím o faktoru klienta (Levitt, Pomerville, \& Surace, 2016; Rennie, 1990; 2001) i výzkumům Jonathana Adlera a kol. (Adler, 2012). V této studii je navíc ukázáno, že aktérství může mít různé podoby, někdy se objevuje až v pozdějších fázích terapie, někdy je impulsivní, jindy kontrolované, př́padně adaptivní.

V naší studii jsme kromě jiného popsali autobiografické zdůvodňování, což je jedním z hlavních procesů, kterým transformujeme vzpomínky do životního př́běhu a ustanovujeme biografickou perspektivu událostí v referenčním rámci celého života (Habermas \& Köber, 2014). Podobný pohled na konstrukci př́běhů o změně v psychoterapii nabízí i výzkum Kühnleinové (1999), která realizovala 49 rozhovorů s bývalými pacienty psychiatrického oddělení. Rozhovory byly realizovány s dvouletým odstupem po ukončení terapie a cílem bylo sledovat, jak se zkušenost psychoterapie odrazí v životním př́běhu. Ukázalo se, že subjektivním kritériem efektivity terapie bylo nalezení vysvětlení pro nemoc v rámci vlastní životní historie, tedy nalezení jakési „autobiografické návaznosti“ (Kühnlein, 1999, s. 278). 
Klienti v rámci svých př́běhů změny rekonstruují svoji minulost takovým způsobem, aby byla pro ně uchopitelná, aby dodala smysl prožité nemoci. Domníváme se, že tyto nové př́iběhy se můžou velmi pravděpodobně stát tzv. sebe-definujícími vzpomínkami (Singer, et al., 2013) jinými slovy zaujmout důležité místo $\mathrm{v}$ životním příběhu, jako vyprávění o zvládnutí těžké životní situace. Pokud jsme schopni vyprávět příběh o těžké situaci anebo těžkém životním období tak, že vyprávění vyústí do koherentního a pozitivního závěru, pak i př́iběhy, které si ohledně tohoto těžkého období vytvoříme, se stanou s velkou pravděpodobností sebedefinujícími pro naše self (Singer et al., 2013). Budou to vzpomínky, které nám budou v nejtěžších chvílích připomínat naši schopnost vyrovnat se s nepříznivou situací (Pals, 2006).

Z pohledu studií o narativním zpracování těžkých životních situací lze konstatovat, že v prezentovaných úspěšných př́bězích změny se často objevovalo tzv. explorativní narativní zpracování, které nastává, když je vypravěč př́běhu otevřen průzkumu svých ambivalentních myšlenek a pocitů, a tedy i prípadné reinterpretaci self (Pals, 2006). Explorativní narativní zpracování pozitivně souvisí s resiliencí a osobní pohodou (Pals, 2006) a zralostí ega (King, 2001).

Při narativní analýze musíme mít také na paměti, že vyprávění je konstrukcí, která má kromě jiného sociální funkci. Vyprávění tedy slouží také k sebeprezentaci a někteří autoři akcentují právě tento rozměr vyprávění jako určité omezení, s nímž je třeba při narativní analýze počítat. Například Riessmanová (2008) zdůrazňuje performativní rozměr narativů, podobně LuciusHoene a Deppermann poukazují na fakt, že narativy jsou charakterizovány selektivitou a "situačně podmíněnými pragmatickými cíli vypravěče" (2000, s. 200). V tomto kontextu lze vnímat některé výroky našich respondentů (zejména výroky v kategorii narativní pozice a hodnoty a přesvědčení) také $\mathrm{z}$ pohledu toho, jak chtěli v situaci výzkumného rozhovoru zapůsobit na tazatele.

\section{Limity studie a možnosti dalšího výzkumu}

I když malý počet participantů může být považován za slabou stránku studie, užitečnost použitých kategorií analýzy byla potvrzena dostatečným množstvím dat. Studie je dále omezena výběrem specifických kategorií narativní analýzy - jejich počet nemusí být definitivní, jedná se spíše o jakési zastavení se „na cestě“, na které je narativní analýza ze své podstaty (Čermák, 2002). Seznam kategorií by mohl být v budoucnu rozšířen o globální pohled z perspektivy kategorie zápletky a žánru.

Dále by mohlo být prínosné podívat se na rozdíly v narativním ztvárnění změny mezi klienty, kteří dosáhli zlepšení, a těmi, kteří se zlepšili málo, anebo vůbec. I když je použití kvalitativních metod pro takové srovnání poněkud diskutabilní a přináší mnoho metodologických výzev, s určitou úrovní vědecké stř́dmosti by se podobná analýza dala zrealizovat.

\section{Závěr}

V této studii jsme sledovali narativní charakteristiky př́iběhů o dosažení změny v psychoterapii, a to s užším zaměřením na klienty, kteří dosáhli klinicky významnou změnu. Výchozí kategorií analýzy byla témata změny, která ukazují jedinečnost každého př́iběhu a odpovídají na otázku „o čem změna je“. Jako další významná kategorie bylo popsáno aktérství, které se může vynořovat až $\mathrm{v}$ průběhu terapie anebo dokonce i několik měsíců po ukončení léčby a může mít různé formy. Kategorie narativních pozic pak ukázala, jak se participanti narativně sociálně umist'ují, např́klad se vymezují, identifikují s druhými i se skupinou. A konečně v kategorii hodnoty a přesvědčení se objevily bohaté variace vysvětlování, zdůvodňování, přehodnoco- 
vání jako procesy, které dopomáhají k narativnímu zpracování a konstrukci příběhu o změně. Zjištění studie umožňují detailní pohled na formy narativního zpracování, které přispívají k dosažení změny v psychoterapii.

Studie byla podpořena $\mathrm{z}$ grantů:

GAČR 14-35577S „Účinné faktory a efektivita skupinové psychoterapie v ČR“

RVO 68081740, jako část Strategie AV21.

\section{Literatura}

Adler, J. M. (2012). Living into the story: agency and coherence in a longitudinal study of narrative identity development and mental health over the course of psychotherapy. Journal of Personality and Social Psychology, 102(2), 367-389. http://doi.org/10.1037/a0025289

Adler, J. M., Skalina, L. M., \& McAdams, D. P. (2008). The narrative reconstruction of psychotherapy and psychological health psychological health. Psychotherapy Research, 18(6), 719-734. http://doi.org/10.1080/10503300802326020

Angus, L. (2012). Toward an integrative understanding of narrative and emotion processes in Emotion-focused therapy of depression: Implications for theory, research and practice. Psychotherapy Research, 22(4), 367-380. https://doi.org/10.1080/10503307.2012.683988

Angus, L., \& Kagan, F. (2013). Assessing client self-narrative change in emotion-focused therapy of depression: An intensive single case analysis. Psychotherapy, 50(4), 525-534. https://doi.org/10.1037/a0033358

Bamberg, M. (2005). Positioning. In D. Herman, J. Manfred, \& R. Marie-Laure (Eds.), Routledge Encyclopedia of Narrative Theory (s. 445-446). Routledge.

Bamberg, M. (2012). Narrative practice and identity navigation. In J. A. Holstein, \& J. F. Gubrium (Eds.), Varieties of narrative analysis (s. 99-124). SAGE Publications.

Bohart, A. C., \& Tallman, K. (2010). Clients: The neglected common factor in psychotherapy. In B. L. Duncan, S. D. Miller, B. E. Wampold, \& M. A. Hubble (Eds.), The heart and soul of change: Delivering what works in therapy (s. 83-111). American Psychological Association. https://doi.org/10.1037/12075-003

Bruner, J. (1996). The Culture of Education. Cambridge: Harward University Press.

Čermák, I. (2002). Myslet narativně (kvalitativní výzkum „on the road“). In I. Čermák, \& M. Miovský (Eds), Sbornik z konference Kvalitativni výzkum třetího tisíciletí (s. 11-25). Psychologický ústav AV ČR, Nakladatelství Albert.

Davies, B., \& Harré, R. (1990). Positioning: The discursive production of selves. Journal for the Theory of Social Behaviour, 20, 46-63. https://doi.org/10.1111/j.14685914.1990.tb00174.x

Dubovská, E., Furstová, J., Růžička, J., \& Tavel, P. (2019). Validity of the Czech Version of the Therapeutic Factors Inventory-Short Form (TFI-S). International Journal of Group Psychotherapy, 69(3), 308-327. https://doi.org/10.1080/00207284.2019.1584527

Epston, D. \& White, M. (1992). A proposal for a re-authoring therapy: Rose's revisioning of her life, and a commentary by Kevin Murray. In S. McNamee, \& K. J. Gergen (Eds.), Therapy as a social construction. Sage Publications. 
Gonçalves, M. M., Matos, M., \& Santos, A. (2009). Narrative therapy and the nature of "innovative moments" in the construction of change. Journal of Constructivist Psychology, 22(1), 1-23. https://doi.org/10.1080/10720530802500748

Habermas, T., \& Köber, C. (2015). Autobiographical reasoning is constitutive for narrative identity: The role of the life story for personal continuity. In K. C. McLean \& M. Syed (Eds.), The Oxford handbook of identity development (s. 149-165). Oxford University Press.

Chrz, V. (2004). Výzkum jako narativní rekonstrukce. In M. Miovský, I. Čermák, \& V. Řehan (Eds.), Kvalitativní prístup a metody ve vědách o člověku III., (s. 21-32). Nakladatelství Univerzity Palackého.

Jacobson, N. S., \& Truax, P. (1991). Clinical significance: A statistical approach to defining meaningful change in psychotherapy research. Journal of Consulting and Clinical Psychology, 59(1), 12-19. https://doi.org/00224006X/9

Juhová, D., Řiháček, T., Cígler, H., Dubovská, E., Saic, M., Černý, M., Dufek, J., \& Evans, C. (2018). Česká adaptace dotazníku CORE-OM: Vybrané psychometrické charakteristiky. Československá psychologie, 62(1), 59-74.

Kazdin, A. E. (2009). Understanding how and why psychotherapy leads to change. Psychotherapy Research, 19(4-5), 418-428. https://doi.org/10.1080/10503300802448899

King, L. A. (2001). The hard road to the good life: The happy, mature person. Journal of Humanistic Psychology, 41(1), 51-72. https://doi.org/10.1177/0022167801411005

Kühnlein, I. (1999). Psychotherapy as a process of transformation: Analysis of posttherapeutic autobiographic narrations. Psychotherapy Research, 9(3), 274-287. https://doi.org/10.1080/10503309912331332761

Levitt, H. M., Pomerville, A., \& Surace, F. I. (2016). A qualitative meta-analysis examining clients' experiences of psychotherapy: A new agenda. Psychological Bulletin, 142(8), 801830. https://doi.org/10.1037/bu10000057

Lieblich, A., Tuval-Mashiach, R., \& Zilber, T. (1998). Applied social research methods, Vol. 47. Narrative research: Reading, analysis, and interpretation. Sage Publications.

Lieblich, A., McAdams, D., \& Josselson, R. (2004). Healing plots : The narrative basis of psychotherapy (1st ed., The narrative study of lives). American Psychological Association.and Interpretation. Sage.

Lincoln, YS. \& Guba, EG. (1985). Naturalistic Inquiry. Sage Publications.

Lucius-Hoene, G., \& Deppermann, A. (2000). Narrative identity empiricized a dialogical and positioning approach to autobiographical research interviews. Narrative Inquiry, 10(1), 199-222. https://doi.org/10.1075/ni.10.1.15luc

Mackrill, T. (2008). Exploring psychotherapy clients' independent strategies for change while in therapy. British Journal of Guidance \& Counselling, 36(4), 441-453. https://doi.org/10.1080/03069880802343837

Madill, A., Sermpezis, C., \& Barkham, M. (2005). Interactional positioning and narrative selfconstruction in the first session of psychodynamic-interpersonal psychotherapy. Psychotherapy Research, 15(4), 420-432. https://doi.org/10.1080/10503300500091249

McAdams, D. P. (1996). Personality, modernity, and the storied self: a contemporary framework for studying persons. Psychological Inquiry, 7, (4) 295-321.

Moertl, K., \& Von Wietersheim, J. (2008). Client experiences of helpful factors in a day treatment program: A qualitative approach. Psychotherapy Research, 18(3), 281-293. https://doi.org/10.1080/10503300701797016 
Pals, J. L. (2006). Narrative identity processing of difficult life experiences: Pathways of personality development and positive self-transformation in adulthood. Journal of Personality, 74(4), 1079-1110. https://doi.org/10.1111/j.1467-6494.2006.00403.x

Rennie, D. L. (1990). Toward a representation of the client's experience of the psychotherapy hour. In G. Lietaer, J. Rombauts, \& R. Van Balen (Eds.), Client-centered and experiential psychotherapy in the nineties (s. 155-172). Leuven University Press.

Rennie, D. L. (2001). The client as a self-aware agent in counselling and psychotherapy. Counselling and Psychotherapy Research, 1(2), 82-89. https://doi.org/10.1080/14733140112331385118

Riessman, C. K. (2008). Narrative methods for the human sciences. Sage Publications.

Singer, J. A., Blagov, P., Berry, M., \& Oost, K. M. (2013). Self-defining memories, scripts, and the life story: Narrative identity in personality and psychotherapy. Journal of Personality, 81(6), 569-582. https://doi.org/10.1111/jopy.12005

Thornhill, H., Clare, L., \& May, R. (2004). Escape, enlightenment and endurance: Narratives of recovery from psychosis. Anthropology and Medicine, 11(2), 181-199.

https://doi.org/10.1080/13648470410001678677

\section{Údaje o autorech}

Mgr. Eva Dubovská, Ph.D. pracuje při vlastní terapeutické praxi jako odborná asistentka na Pražské vysoké škole psychosociálních studií a jako výzkumný pracovník v Psychologickém ústavu AV ČR a v Institutu sociálního zdraví Univerzity Palackého. Mezi její výzkumné zájmy patří změna $v$ psychoterapii, resilience, narativní analýza.

Kontaktní údaje:

Adresa: Pražská vysoká škola psychosociálních studií, s.r.o., Hekrova 805, Praha 4

Email: eva.dubovska@centrum.cz

Doc. PhDr. Vladimír Chrz pracuje jako výzkumník v Psychologickém ústavu AV ČR. Přednáší na Katedře psychologie PedF UK v Praze. Z hlediska narativního a psychosémiotického př́stupu zkoumá témata, jako jsou expresivita, resilience, ego-integrita ad.

\section{Kontaktní údaje:}

Adresa: Psychologický ústav AV ČR, Hybernská 8, Praha 1

Email: chrz@praha.psu.cas.cz

Dubovská, E., \& Chrz, V. (2020). Př́iběhy změny ve skupinové psychoterapii: narativní charakteristiky úspěšné změny. E-psychologie, 14(2), 52-64. https://doi.org/10.29364/epsy.372 